theory and experiment in the field of co-ordination chemistry provides, perhaps for the first time, a climate in which experiments are designed to test the quantitative predictions of electronic theory; this must prove beneficial to both.

The organization of the Conference, both of the scientific meetings and the more social occasions, was uniformly excellent. All those who were present must be grateful to the members of the Chemical Society committees who were responsible for it and to those industrial concerns which, by their financial support or by acting as hosts, helped to make the meeting so successful.

\title{
THE BRITISH COAL UTILIZATION RESEARCH ASSOCIATION
}

\section{TWENTY-FIRST ANNIVERSARY OPEN DAYS}

$\mathrm{T}$ HE aim of the Association, from the time of its inception in 1938, has been "to promote research and other scientific work in connexion with the utilization of coal and its derivatives". Some of the achievements of twenty-one years were displayed at the research station during April 22-24.

In 1938, nine experimentalists worked in a single room, $12 \mathrm{ft}$. square, in Victoria Street, London. To-day the British Coal Utilization Research Association occupies a 20-acre site at Leatherhead, and is one of the largest of the thirty-nine industrial research associations supported by the Department of Scientific and Industrial Research; of its total staff of some 300 , eighty are graduates or equivalent and a similar number are research assistants, representative of most of the recognized fields of physical science, from mathematics through the several branches of chemistry and physics to large-scale engineering.

The interests of the Association are many-sided, and this was reflected in the distinctive character of each of the three open days. April 22 was primarily 'members' day'; through its membership the Association forms a link between the four nationalized industries (coal, gas, electricity, transport) and about 150 other members (comprising individual firms and trade associations) which include industrial appliance makers, coal distributors and coal consumers. The Minister of Power, the Right Hon. Lord Mills, was the guest of honour, and in addressing a large and distinguished gathering at luncheon, he observed that the occasion marked the coming-of-age of an Association which had long since established itself as one of the most important and progressive industrial research organizations in Britain.

On the second day the guests were mainly drawn from the field of research; Government departments, research associations, universities and technical colleges were strongly represented. On the morning of the final day parties from local colleges and schools predominated, thus emphasizing the practical interest taken by the British Coal Utilization Research Association in educating young people in the science and technology of coal. In the afternoon the Association was honoured by a visit of a party from the London Section of the Royal Institute of Chemistry; and the day was fittingly concluded by a lecture to this party and other chemists by Prof. R. G. W. Norrish on recent work at Cambridge on flash photolysis in gases.

Throughout its history the British Coal Utilization Research Association has been in close touch with university thought and investigation and has itself maintained a strong programme of basic research. One well-known example of the effectiveness of this approach is the outcome of the experiments on coal breakage which were started in that small over- crowded laboratory in London in 1938. After some years of investigation, in collaboration with the British Colliery Owners Research Association, a specification for grading coal by size was drawn up, and this has been accepted by the National Coal Board as a basis for preparing and marketing coal. Another example of the application of basic research, also exhibited in the Physics Department, was the cone mill. Following a survey of the factors determining the power required for grinding coal to a given size, determination of the Hardgrove grindability index, and measurement of the intrinsic physical and mechanical properties of coal, a matrix theory of coal breakage was developed and the first cone mill was built to test this theory: now its engineering utility is being studied.

Some of the modern techniques being used to investigate both the chemical and the physical aspects of coal constitution were displayed. Research into the chemical basis of the plastic softening of coals, with the view of achieving better control of coking properties, has recently made considerable progress, and current knowledge of the mechanism was illustrated diagrammatically alongside the special apparatus employed. Another exhibit was of interest as the first complete conversion, in a single step, of coal to chemical products without simultaneous production of tar or solid residue : low-rank coals have been treated with chlorine trifluoride, producing a range of chlorofluorocarbons (from colourless oils to resin-like solids) possessing chemical and physical properties that indicate their possible suitability for certain industrial applications.

Considerable work by the Association over a number of years on the ultra-fine porous structure of coal and its development during carbonization has led to the placing, by the U.K. Atomic Energy Authority, of a research contract for fundamental work on the graphite used as moderator in nuclear reactors. This investigation has already shown that closed pores in the graphite become accessible during its reaction with oxidizing gases, and an estimate of the importance of internal burning has been obtained.

Among the current major problems facing the coal industry are : improvement of methods for using small coal; meeting the challenge of competition from oil ; and assistance in the implementation of the Clean Air Act. Research by the Association has, therefore, been directed especially towards : $(a) \mathrm{im}$ proving and devising appliances suitable for burning small coal ; (b) developing methods for the automatic control of combustion; and (c) investigations on reduction of atmospheric pollution from coal-burning appliances.

One of the most important current needs is a method of converting small coal cheaply to gas, and ultimately 
to oil. The Association's experimental slagging gasifier, built under contract with the Ministry of Power, at present consumes about a ton of fuel an hour and can take, in short tests, up to half of this in the form of pulverized coal. It has been operated successfully at various ash-levels and over a range of ash fluidities. Background studies have made possible the tentative correlation of slag viscosity-temperature curves with slag composition; and improved methods of analysis have enabled the important constituents of ash to be determined at the rate of four samples a day.

The automatically controlled small-pipe, forcedcirculation central heating system, developed by the Association, is being actively promoted by the Coal Utilization Council, and was displayed by them in the exhibition they had arranged on the site. Also on view in the Council's exhibition were some of the thirty or more designs of free-standing convector fire with restricted throat, a type of appliance that has been developed by the British Coal Utilization Research Association.

The Association's Calorimeter Room has taken its place as an absolute standard for testing domestic appliances. A method of automatic control for miniature chain-grate stokers, used to fire centralheating boilers ( $\frac{1}{2}-2$ million B.T.ण./hr.) in offices or blocks of flats, has been devised, and a unit burning $\frac{1}{2}$-in. small coal smokelessly and at high efficiency is now being tested.

An air-fuel ratio controller has been developed within the Association for fitting to stokers of Economic and Laneashire boilers in order to take much of the responsibility for maintaining the correct ratio of fuel to air out of the hands of the fireman, and one of these controllers was in use on the boiler used for site heating.

A first step towards finding means for reducing atmospheric pollution from coal-burning appliances has been made through the work on the measurement of dust and grit emission from boiler furnaces. The methods of sampling dust from stacks developed by the Association were on view and have aroused much interest in those concerned with enforcing or complying with the Clean Air Act. The automatic particle-sizing apparatus developed by the Association was displayed; with special care it can be employed down to 2 microns and can be used to carry out eight analyses a day.

The study of problems arising from the deposition of inorganic solids and corrosive liquids from flue gases in water-tube boilers forms an important part of the Association's work; these problems are investigated both in the laboratory and at power stations. Large- and small-scale equipment used in these investigations was on view. Special measuring apparatus devised for this work was also demonstrated.

It has not been possible in this short account to mention more than a selection of the exhibits. A fuller account of the current researches is contained in the annual report of the British Coal Utilization Research Association for 1958, and a bibliography of the Association's publications during 1938-59 is to be published in the near future.

\section{THE EAR UNDER WATER}

\begin{abstract}
A DISCUSSION meeting devoted to "The Ear A under Water" was held at the Royal Society on March 12. In his opening survey, Prof. O. Lowenstein pointed to the fact that even in its most highly evolved state the vertebrate ear is a dual-or evon triple-purpose sense organ. It incorporates receptors for angular acceleration (semicircular canals), for linear acceleration including gravitational stimuli (otolith organs) and for oscillatory changes in linear acceleration such as vibration in general and sound in particular (otolith organs, cochlea). The vertebrate ear appears to be a phylogenetic novelty derived by modification from the lateral-line organs of early fish-like vertebrates and not from the statocyst of the invertebrates. Thus, the ear is probably not the comparative-anatomical homologue of the invertebrate statocyst. There is no doubt, however, that the two organs are functionally analogous. It was therefore considered desirable to review recent work on the invertebrate statocyst in the context of the symposium.
\end{abstract}

Dr. Melvin Cohen (University of Oregon) described the anatomy of the statocyst of the lobster, Homarus americanus, and discussed the results of an electrophysiological analysis of its function. It contains two types of position receptors, one for the monitoring of absolute position and one which also indicates the direction from which a certain position is approached. A third receptor type functions as an acceleration receptor and is insensitive to position. There are receptors responding to vibration of the solid substrate, but no reactions to air-or water-borne sound could be registered. Dr. Cohen pointed to the striking similarities between the responses from the crustacean statocyst and those from the various end organs of the vertebrate labyrinth.

In a paper on the cephalopod statocyst, Prof. $J$. Z. Young gave a detailed description of the morphology of the statocyst of the octopus. This remarkable sense organ, too, shows a most interesting and functionally suggestive number of items of structural convergence with the vertebrate labyrinth. Apart from a vertically placed macula with otolith, there is a crista which has sections in three planes of space, each section being associated with a separate nerve. The sensory hairs are ensheathed in a matrix of unknown composition forming cupulæ reminiscent of those found in the labyrinth. Large neurons having dentritic endings as well as hair processes underlie the sensory cells of the crista and appear to make synaptic contact with them, although the hair cells themselves are primary sensory cells equipped with centripetal axons. A hand-shaped vane (the so-called anti-crista) protrudes into the endolymphatic space and seems to be so arranged as to protect the vertical section of the crista from overstimulation when the octopus suddenly accelerates forward, as it does on attacking prey.

Prof. Young stressed that there is no behavioural evidence of hearing in the cephalopods, but on anatomical grounds there is no reason why the cephalopod statocyst should not be potentially capable of vibration reception or even hearing, besides its manifestly obvious function as an organ of static and dynamic spatial orientation. 